\title{
The hidden role of the subsurface for cities
}

Loretta von der Tann MSc (ETH, Civil Eng), SIA

PhD Researcher, Department of Civil, Environmental and Geomatic Engineering, University College London, London, UK

Nicole Metje PhD, Dipl-Ing, MInstCES, ASCE, FHEA

Reader in Infrastructure Monitoring, School of Engineering, Department of Civil Engineering, College of Engineering and Physical Sciences, University of Birmingham, Birmingham, UK
Han Admiraal MBA, BSc, CEng

Managing Director, Enprodes Management Consultancy BV, ITA Committee on Underground Space, Rotterdam, the Netherlands

Brian Collins CB, FREng, FICE

Professor of Engineering Policy, Department of Civil, Environmental and Geomatic Engineering, University College London, London, UK

The evolution of cities is directly linked to their subsurface: the local geology and hydrogeology alongside the history of human interventions are the basis for the present structure and organisation of cities and affect the prospects for future developments within and above the ground. The underground serves multiple purposes in cities including; providing stability for buildings, providing drinking water and materials, serving as a heat source or retention basin, and accommodating infrastructure and developments. In the face of growth predictions and climate change, interdependencies between urban planning objectives and the subsurface, such as placing infrastructure underground to release surface congestion, remediation of brownfields for development, or prospecting for geothermal energy, become ever more important. This paper reviews current initiatives in industry, policy and research in the UK, which aim for changes in urban subsurface management and governance. It identifies the multitude of planning topics in which the subsurface implicitly features, many of which are commonly only addressed at project level. It highlights that the wider impact of these interventions on underground space and the development of the city is not considered. Consequently, the value of the subsurface for sustainable and resilient development of cities may not be realised.

\section{Introduction}

Urban dwellings heavily rely and affect their subsurface. The availability of resources in the subsurface, in particular water, building materials and fertile land was a key parameter for the initial choice of location for human settlements.

Specific functions such as agriculture for food production are now sourced outside of the cities themselves (Deelstra and Girardet, 2000) but the relationship between a city and its subsurface remains close. As illustrated in Figure 1, the urban subsurface now serves as historical archive, as support for surface structures, and as space for developments, transport and utility infrastructure.

The local geology determines the availability of water, materials and geothermal energy, influences the form and method of construction of engineered structures (Bell, 2003) and provides ecosystem services such as temperature regulation or nutrient cycling (Rawlins et al., 2015). As such, several topics addressed in the UN Habitat New Urban

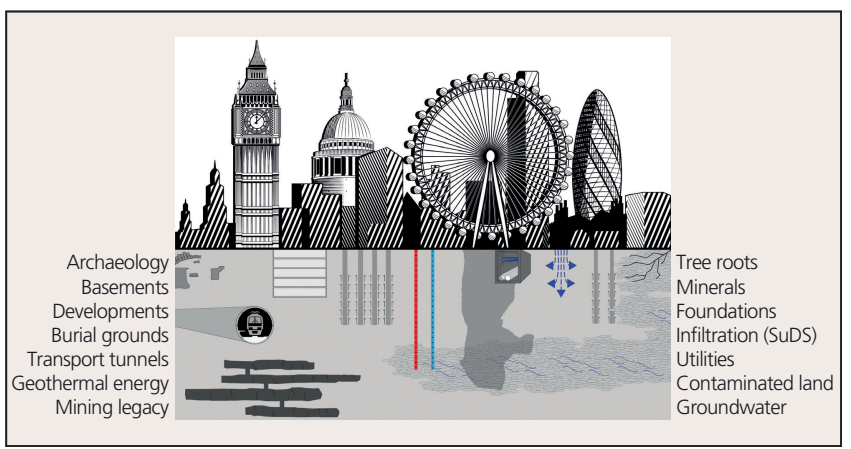

Figure 1. The multitude of human uses and their legacy in the urban subsurface (not to scale, geological features are not shown). Skyline reprinted with permission of Neil Watson, www.neil-watson.co.uk. SuDS, sustainable drainage systems
Agenda (UN Habitat III, n.d.), such as infrastructure provision or ecosystem and resource management, implicitly build on subsurface functions. Admiraal and Cornaro (2016) point out that use of the subsurface can contribute to seven of the 17 sustainable development goals proposed by the United Nations (UN, 2017).

In turn, humans have substantially influenced the local subsurface environment in and around cities through mining activities, levelling of ground, building up of artificial ground, or reclaiming land from the sea (Price et al., 2011). Developments (Curiel-Esparza et al., 2004), contamination of soils and groundwater (Meuser, 2010), modification of the local groundwater regimes (Foster and Hirata, 2011), or ground sealing (Scalenghe and Marsan, 2009) are just some of the human interventions that continue to have a significant effect on the formation and condition of the local geology and in turn on the feasibility of new projects. Land remediation and waste management of excavated soil, for example, are prevailing challenges.

Construction of engineered structures in the ground and other projects affecting the subsurface are commonly decided upona a case-by-case basis and approved by planning authorities following a specified process. Several authors have suggested a more explicit integration of the subsurface into urban planning policies, for instance through master plans (Bobylev, 2009) or mapping of use potentials (Doyle, 2016). The recent push to make cities more resilient to extreme events increases the necessity for a shift towards whole-system approaches that integrate below ground, above ground and at-grade developments (Nelson, 2016).

To understand the baseline on which a holistic approach to subsurface planning would have to build in England, this paper first outlines the persistent challenges for gathering subsurface information and reviews recent approaches to map and survey services in the shallow subsurface.

A brief outline of how the subsurface is governed in the current English planning regime shows a predominance of ecological and regulatory institutions. It is demonstrated that accessibility and 
Civil Engineering

Volume 171 Issue CE6
The hidden role of the subsurface for cities

von der Tann, Metje, Admiraal and Collins understanding of data about the subsurface and the embedded assets can stimulate new ideas about how to plan holistically and prepare our cities for the future.

The challenges stemming from the local geology cannot be disregarded, but the perspective can be changed from seeing the subsurface as a constraint to understanding it as an opportunity to improve urban spaces.

\section{Gathering subsurface information}

A necessary basis for subsurface planning is a sound understanding of the local geological and hydrogeological conditions as well as a record of the spatial and temporal distribution of existing and future planned activities. Despite the constant advancement of mapping and visualisation tools such as geographic information systems or building information modelling, the depth-related data to feed into these models remain dispersed.

Whereas surface geological mapping is undertaken systematically at a national level, information about the variation in geological and geotechnical properties with depth is often only retrieved by way of individual exploration or construction schemes. The volume, distribution and quality of data arising from these sites determine the extent to which these disparate data can be amalgamated into a consistent geological model.

Data acquisition and management is described as particularly challenging in urban settings where these data are highly inhomogeneous, and numerous data types describing the natural and anthropogenic subsurface persist (Watson et al., 2017). The various formats for borehole logs from site investigations usually do not include details about quality and uncertainty (Tegtmeier et al., 2014) and the data are not commonly shared with a wider community.

To enable harmonisation and re-use of geological and geotechnical data, in the UK the Association for Geotechnical and Geoenvironmental Specialists (AGS) had already in 1992 launched a new data format (AGS format) comprising the manifold industry requirements (AGS, 2017). In parallel, the British Geological Survey (BGS) collated a national geotechnical properties database which largely builds on voluntary data deposition by private and public institutions (BGS, 2017a) and provides controlled access to the data, predominantly for the geotechnical and engineering community.

As of 2012, the BGS in collaboration with Glasgow City Council (GCC) developed 'Accessing subsurface knowledge', a network of private and public institutions to improve ingestion and data reporting into the database (Bonsor, 2017). The AGS format has been widely accepted in the industry (Bland et al., 2014) and some national stakeholders now include AGS data donation to the BGS national data repository as a requirement of framework contracts (Bonsor, 2017).

Establishing a similar process for data about buried infrastructure appears to be much more difficult. The exact location and condition of utility lines and cables is often unknown (Thomas et al., 2009), and the available data have to be obtained separately for each site from a multitude of infrastructure owners and utility providers, making planning of new structures in the vicinity of these services more and more challenging.

At the same time, many assets date back to Victorian times, and maintenance requirements are increasing (Costello et al., 2007). Because long trenches in busy urban areas are unfeasible, utility companies begin to develop deep tunnels when large sections of their shallow assets need replacement. The London power tunnels (National Grid, 2017) are one example of this development.

The need to reduce traffic disruption and the associated costs due to streetworks (Goodwin, 2005) and at the same time facilitate access to services has led to a range of industrial, political and academic initiatives in recent years. For example, London and Kent introduced lane rental schemes to incentivise more efficient and collaborative execution of streetworks (DfT, 2015). Extensive research was carried out on the development of a multisensor approach to detect the position and assess the condition of underground assets without excavating (MtU, 2012).

In April 2017, BSI launched a publicly available specification (PAS) setting out processes of gathering, recording and sharing of asset data (BSI, 2017). PAS 256 followed PAS 128 for underground utility detection, verification and location (BSI, 2014) and defines a standardised data protocol to enable data sharing similar to the AGS format for geotechnical data. The application of PAS 256 is not mandatory but it is anticipated that the prospect of easier data exchange between infrastructure owners will encourage its adoption, with large projects leading the way (Phull, 2017).

Even if a standardised data format would be accepted, there remains a lack of a central data repository and, although it is encouraging owners to move to a digital format, PAS 256 (BSI, 2017) does not cover integration of the old, paper-based records. One initiative to mention in this context is the London Infrastructure Map initialised by the Greater London Authority in 2015 (Figure 2). The map visualises data from utilities, boroughs and developers and aims to improve infrastructure planning and delivery (London Assembly, 2016). Despite the general concept being supported by the infrastructure companies, concerns about data confidentiality and security delayed the process (McMunnigall, 2017, personal communication).

An international example addressing the challenge of subsurface data collection and management is the baseline underground register established in 2015 in the Netherlands. The Basisregistratie Ondergrond (BRO) consolidates geological and exploration data as well as data about mining activities and the associated structural assets (BRO, 2017a).

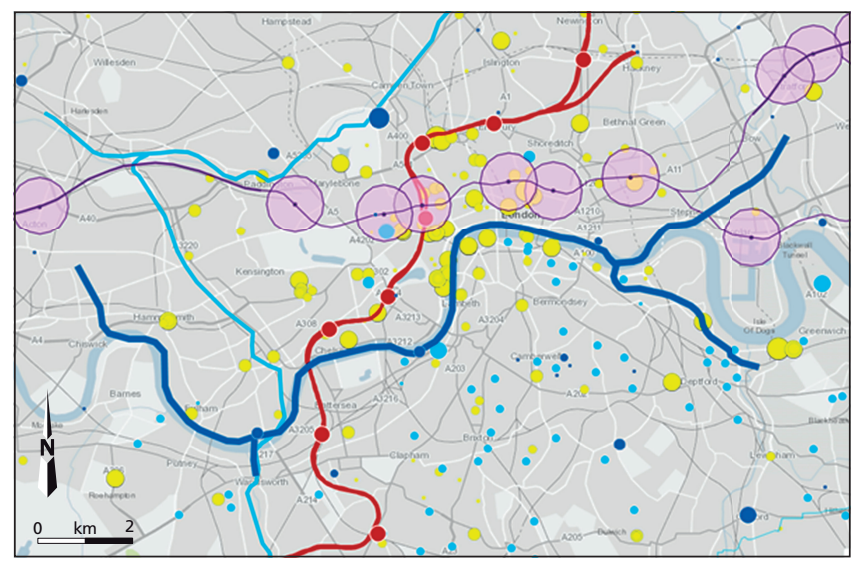

Figure 2. Snapshot of the London Infrastructure Map (https://maps.london.gov.uk/ima/) showing future investments in the water and energy sectors (dark and light blue, respectively) as well as Crossrail 1 (purple) and the safeguarded route for Crossrail 2 (red). 
However, to create new legislation focusing on the subsurface as an entity in its own right proved too complex, and structural assets in the shallow subsurface such as underground car parks, basements, tunnels or cables and pipelines, will not be covered in the BRO. These structures will instead be integrated in another of a total of 12 baseline registers that are being created by the Dutch government and will provide open source data for future decision-making (BRO, 2017b). With these registers the Netherlands implement regulation stemming from the EU Inspire programme that aims to create a spatial data infrastructure for EU environmental policies, and policies or activities potentially having an impact on the environment (European Commission, n.d.).

The described initiatives focus on mapping and evaluation of existing assets and ground conditions that build on bottomup involvement of the affected industries. A step-change in data sharing will be necessary to oversee the current situation, allow analysis of interdependencies between present and future interventions and evaluate the practicability of tapping into the potential for future developments or activities in the subsurface.

Also, potential data gaps should be assessed as the type and amount of data recorded. Which data are recorded in the first place remain driven by geological research requirements and projectspecific site investigations and do not react to specific needs of other domains such as, for instance, urban planning.

\section{The subsurface in UK planning regulations}

If baseline data are one cornerstone for subsurface planning, understanding of the current governance regime is another. Many of the services and functions that are occupying subsurface space are in some way covered in current UK environmental and planning policy and legislation. However, the detail to which they are considered and the level on which they are regulated differ widely.

For example, much of the environmental regulation stems from EU directives, but policies around basement development, if any, only exist at local level. Whereas a presumption exists that land ownership extends into the subsurface (HM Land Registry, 2015), a range of statutory rights and legal agreements facilitate the presence of infrastructure in the subsurface (see Darroch et al., 2016). In addition, ownership and safeguarding of minerals can significantly influence planning decisions for developments above and below ground.

Despite urban policy not being an EU responsibility, the European Commission over the past decade emphasised the urban dimension (European Commission, 2011, 2017). However, the responsibility for spatial planning remains with the member states. In the UK, the land-use planning system in all four countries (devolved regions) is plan-led, meaning that formal development plans on local and regional levels set out policies that serve as a framework for decision-making about planning applications.

Table 1. EU directives affecting governance of the urban subsurface (selection by author)

\begin{tabular}{|c|c|c|c|}
\hline Year & EU directive* & $\begin{array}{l}\text { Topics relevant for the urban } \\
\text { subsurface }\end{array}$ & Main effective transposition in England \\
\hline 1991/1998 & $\begin{array}{l}\text { Urban waste water } \\
\text { treatment (EC, 1991, } \\
\text { 1998) }\end{array}$ & $\begin{array}{l}\text { Waste water treatment including } \\
\text { prevention of leakage of collecting } \\
\text { systems }\end{array}$ & $\begin{array}{l}\text { The Urban Waste Water Treatment Regulations } 1994 \text { (HMG, } \\
\text { 1994) and The Urban Waste Water Treatment (England and } \\
\text { Wales) (Amendment) Regulations } 2003 \text { (HMG, 2003) }\end{array}$ \\
\hline 2000 & $\begin{array}{l}\text { EU water framework } \\
(E C, 2000)\end{array}$ & $\begin{array}{l}\text { Surface water, groundwater and } \\
\text { groundwater-dependent ecosystems }\end{array}$ & $\begin{array}{l}\text { The Water Environment (Water Framework Directive) } \\
\text { Regulations } 2017 \text { (HMG, 2017a) }\end{array}$ \\
\hline 2001 & $\begin{array}{l}\text { Strategic environmental } \\
\text { assessment (EC, 2001) }\end{array}$ & $\begin{array}{l}\text { Incorporates environmental } \\
\text { considerations in strategic planning, } \\
\text { including land-use planning }\end{array}$ & $\begin{array}{l}\text { The Environmental Assessment of Plans and Programmes } \\
\text { Regulations, } 2004 \text { (HMG, 2004) }\end{array}$ \\
\hline 2006 & $\begin{array}{l}\text { Extractive waste (EC, } \\
\text { 2006a) }\end{array}$ & $\begin{array}{l}\text { Management of geological materials that } \\
\text { are considered waste }\end{array}$ & $\begin{array}{l}\text { The Environmental Permitting (England and Wales) } \\
\text { Regulations } 2010 \text { (HMG, 2010) }\end{array}$ \\
\hline 2006 & $\begin{array}{l}\text { Groundwater (EC, } \\
\text { 2006b) }\end{array}$ & Protection of groundwater & $\begin{array}{l}\text { Groundwater Regulations } 2009 \text { (HMG, 2009a) and } \\
\text { Groundwater (Water Framework Directive) (England) } \\
\text { Direction } 2016 \text { (Defra, 2014) }\end{array}$ \\
\hline 2007 & $\begin{array}{l}\text { Infrastructure for spatial } \\
\text { information in the EC } \\
\text { (Inspire) (EC, 2007a) }\end{array}$ & $\begin{array}{l}\text { Requires improvement of access to and } \\
\text { sharing of spatial data }\end{array}$ & $\begin{array}{l}\text { The Inspire Regulations } 2009 \text { (HMG, } 2009 \mathrm{~b}) \text { and The } \\
\text { Inspire (Amendment) Regulations } 2012 \text { (HMG, 2012) }\end{array}$ \\
\hline 2007 & Flood (EC, 2007b) & $\begin{array}{l}\text { Assessment and management of flood } \\
\text { risks }\end{array}$ & The Flood Risk Regulation 2009 (HMG, 2009c) \\
\hline 2008 & $\begin{array}{l}\text { Waste framework (EC, } \\
\text { 2008) }\end{array}$ & Disposal of excavated soil & $\begin{array}{l}\text { The Waste (England and Wales) Regulations } 2011 \text { (HMG, } \\
\text { 2011) }\end{array}$ \\
\hline 2009 & $\begin{array}{l}\text { Renewable energy (EC, } \\
\text { 2009) }\end{array}$ & $\begin{array}{l}\text { Legally binding targets for the share of } \\
\text { renewable energy sources }(20 \%) \text { and } \\
\text { definition of 'geothermal energy' }\end{array}$ & The Renewables Obligation Order 2015 (HMG, 2015) \\
\hline $2011 / 2014$ & $\begin{array}{l}\text { Environmental impact } \\
\text { assessment (EC, 2011, } \\
\text { 2014) }\end{array}$ & $\begin{array}{l}\text { Principles for environmental impact } \\
\text { assessment of projects including the } \\
\text { description of effects on cultural heritage } \\
\text { (archaeology) and soil and water }\end{array}$ & $\begin{array}{l}\text { The Town and Country Planning (Environmental Impact } \\
\text { Assessment) Regulations } 2017 \text { (HMG, 2017b) and The } \\
\text { Infrastructure Planning (Environmental Impact Assessment) } \\
\text { Regulations } 2017 \text { (HMG, 2017c) }\end{array}$ \\
\hline
\end{tabular}


Civil Engineering

Volume 171 Issue CE6
The hidden role of the subsurface for cities

von der Tann, Metje, Admiraal and Collins
Each local authority prepares its own local planning policies following the guidelines set out in national and potentially regional legislation (House of Commons, 2016). European regulation and regulation stemming from European directives serve as material consideration for local planning decisions.

A selection of directives that cover subsurface-related topics and - without being exhaustive - the most recent and relevant transposition documents in England is given in Table 1. Many of these mainly environmental topics in England are included in the national planning policy guidance, and are therewith acknowledged as primary concern for planning, see Table 2. Alongside the national planning policy framework, the guidance sets out the major guidelines for local planning authorities in England to prepare their local plans. Similar legislation and guidance has been issued in the other three UK countries.

Further to the regulation originating from EU directives, as well as the national and regional policies, local authorities can emphasise specific planning topics or include additional aspects in their local plans. Some of these are directly concerned with subsurface space use. For instance, mainly as a reaction to citizens' complaints about large basement extensions (Reynolds and Reynolds, 2015), five London boroughs developed supplementary planning documents or specific policies on basement developments.

Another example is the City of London, where the use of 'pipe subways', accessible tunnels in which several utilities can be fitted and which eliminate the need for repeated excavation (Hunt et al., 2014), is mandatory wherever feasible (City of London, 2013).

Other topics are covered in the local plans that imply intensified use of underground space without stating it explicitly. The promotion of high-rise buildings, for example, often entails deep foundations, and protection of open space or efforts to recover open space might incentivise construction of underground developments. Also, the general intention to densify as a reaction to housing needs could incentivise the development of underground space for facilities that do not rely on daylight as well as increase the demands for underground infrastructure.

Beyond the process of gaining planning approval by a local authority, the use of underground space for major infrastructure projects can be approved on a national level through specific Acts of parliament (e.g. Crossrail Act 2008, 2008; Channel Tunnel Act 1987, 1987) or more recently through the national significant infrastructure scheme that was introduced with the Planning Act 2008 (2008).

Note that the objective towards the respective activities in the subsurface is not uniform. Whereas for groundwater management the main objective is protection and a balanced use of the water resource, flood management can require the provision of subsurface space for retention purposes. Policies on renewable energy, high-rise buildings open spaces as well as decisions about major infrastructure schemes explicitly encourage or determine the utilisation of subsurface space. The latter are of particular interest as they might bring about an increase in subsurface structures and thus irreversible modifications to the subsurface resource.

It becomes apparent that the current governance of subsurface space in England is largely sectoral and project centred rather than based on the premise to control all activities in a given volume. The planning system in the UK provides a framework for mediation of different interests when deciding about planning applications in which the listed guidance documents serve as material considerations.

However, each aspect is addressed separately and the interdependencies dealt with in a particular application are restricted to already existing or planned activities in the project vicinity. The effect of the individual regulations on plan making from the outset seems to be limited.

\section{New approaches for integrated subsurface planning}

The brief summary of relevant English regulation related to subsurface planning highlights that there is considerable scope for improvement. In recent years the topic of conflicting space claims in the subsurface and how this should be regulated appeared on the policy agenda in a range of countries including Norway, Sweden, Finland, China and Japan (Sterling et al., 2012).

Table 2. National planning policy guidance relevant for the urban subsurface (DCLG, 2016)

\begin{tabular}{|c|c|}
\hline National planning policy guidance & Topics relevant for the urban subsurface \\
\hline Air quality & Green infrastructure and modes of transport with low impact on air quality \\
\hline Climate change & $\begin{array}{l}\text { Renewable energy technologies, sustainable transport, availability of water and water } \\
\text { infrastructure, and flood risk }\end{array}$ \\
\hline $\begin{array}{l}\text { Conserving and enhancing the historic } \\
\text { environment }\end{array}$ & Archaeological sites and undesignated buried remains of archaeological interest \\
\hline Environmental impact assessment & Effects on soil and water, archaeological heritage and effects of the use of natural resources \\
\hline Flood risk and coastal change & All kinds of flood risks including surface and groundwater flooding, and sustainable drainage systems \\
\hline Land affected by contamination & Planning duties with regard to land contamination and its possible effects \\
\hline Land stability & Planning duties with regard to land instabilities \\
\hline Minerals & Safeguarding and extraction of mineral resources \\
\hline Natural environment & Protection of ecosystems, in particular soil \\
\hline $\begin{array}{l}\text { Tree preservation orders and trees in } \\
\text { conservation areas }\end{array}$ & Protection of trees including tree roots \\
\hline Waste & Landfill and excavation waste \\
\hline Water supply, waste water and water quality & Identification of suitable sites for new or enhanced infrastructure \\
\hline
\end{tabular}


The 2015 revision of the spatial planning law in Switzerland calls for sustainable use of the subsurface (RPG, 2015), and research commissioned by the Federal Environment Agency in Germany concluded that the application of existing planning instruments to underground space would be possible and should be established to manage current and prevent future use conflicts (Bartel and Janssen, 2016).

The importance of the subsurface for urban development has also been addressed in major research projects. At least two volumes of the UN Atlas of Urban Geology focused on the interface to urban planning (UN, 2001, 2003) and in 2013-2017 the BGS chaired a research action supported by the European Cooperation in the field of Scientific and Technical Research (Cost) that addressed the question of how information and knowledge about the subsurface can benefit urban decision-makers. 'Cost Sub-Urban' involved a variety of municipalities and geological surveys and was not focused on academic institutions (Cost, 2017).

In the UK, GCC was actively involved in the Cost action and itself takes a progressive stance. The new city development plan, adopted in March 2017, explicitly touches on the subsurface in that it includes geodiversity in its policy on the natural environment, and committed the council to address subsurface infrastructure as well as ground source heat in a supplementary guidance document on resource management (GCC, 2017a, 2017b).

The development of Glasgow is closely linked to its subsurface environment, not least through the legacy of mining and heavy industry that throughout past centuries has caused substantial modifications to the ground surface. Many parts of the city are underlain by shallow abandoned mine workings which still cause settlements due to local collapses (Whitbread et al., 2016). To improve the knowledge of the distribution and depth of these mine workings and enable the regeneration of the associated areas in the city, BGS in 2002-2003 initiated the development of a three-dimensional geological model of the area (Campbell et al., 2010; Whitbread et al., 2016). The model also improved the understanding of groundwater flow and the location of flooding in Glasgow (Bonsor et al., 2013).

Continuing collaboration between GCC and the BGS, as well as knowledge exchange with other European cities through the Cost network, enabled the council to facilitate a growing awareness of policy-makers of the value of the subsurface environment and the information about it (Bonsor, 2017; Whitbread et al., 2016).

GCC now explicitly uses subsurface information in its planning processes to understand correlations and synergies between subsurface properties and other planning aspects like connectivity or access to open space. In this context, the council also explores possibilities to tap into potentials of utilising subsurface resources to regenerate above-ground areas or make council assets cost neutral (Dick, 2017). GCC and the BGS are now working with other councils to publicise this new approach and share their experience (BGS, 2017b).

As the regulation and governance of subsurface space, the functions it embeds and services it provides, is fragmented, initiatives like the one taken in Glasgow largely rely on the initiative of individuals in the respective institutions. There is currently a focus on acquisition and sharing of data. These data provide a useful tool for current projects as well as a necessary basis for a contingent governance framework.

Whereas the growing demand for space drives the development of such frameworks, in particular places such as Singapore and Hong Kong, integration of the subsurface into urban development strategies is likely to become more pivotal with cities developing resilience strategies.

As a response to climate change effects, uses such as flood retention capacities, storage capacities, local energy sourcing and potentially underground housing can be expected to become more important. These considerations also affect smaller cities in which aspects of underground developments as a result of growing densities and land prices are less relevant. For example, Rotterdam and Arnhem in the Netherlands have started the process of integrating the subsurface into urban planning motivated through the need for sustainable development and urban resilience.

Glasgow and other European cities herald the start of a mind shift by encouraging the use of information about the subsurface to guide new planning policies. They show that understanding the subsurface and well communicated engineering knowledge can change perception of place and generate new ideas about the cities' development prospects. The role of engineers in this context is to learn from existing projects and to develop metrics that capture and convey the meaning and complexity of the urban subsurface as well as the embedded infrastructure systems (Nelson, 2016).

Ultimately, a holistic approach to subsurface planning and governance will integrate data acquisition and management, legislation and governance, as well as expert knowledge.

\section{Conclusions}

Over the last decades, both in the UK and overseas, a number of initiatives have emerged that aim to acknowledge the role of the subsurface for cities and improve availability and utilisation of subsurface data.

Pressures from climate change and urban growth will lead to intensified use of the urban subsurface and reinforce the need for a more organised response to potentially conflicting space claims. Contemporary legislation and planning might be applicable but only if a sufficient data base is available and existing interactions and potential conflicts are understood.

Acquiring the data is already an enormous task. While the subsurface and according governance are changing, with Glasgow as an example, there is still a long way to go before a holistic, multilevel approach towards the subsurface, covering environmental, structural and geological aspects of underground space, is realised.

The subsurface starts to be included in the search for discrete spatial or energy solutions but it became apparent that engineers need to consider the effects of human interventions not only on the geology or hydrology but also on existing structures as well as the ecosystem services the subsurface provides.

Communication of the associated risks and opportunities to the various actors involved in decision-making about what can or cannot be done below the surface is key to ensure that the value of the subsurface is not diminished.

\section{Acknowledgements}

This work was supported by the EPSRC funded Centre for Urban Sustainability and Resilience at University College London. The authors would like to thank Gillian Dick, GCC, and Helen Bonsor, BGS, for their comments on the paper. 
Civil Engineering

Volume 171 Issue CE6
The hidden role of the subsurface for cities

von der Tann, Metje, Admiraal and Collins

\section{References}

Admiraal H and Cornaro A (2016) Why underground space should be included in urban planning policy - and how this will enhance an urban underground future. Tunnelling and Underground Space Technology 55: 214-220.

AGS (Association of Geotechnical \& Geoenvironmental Specialists) (2017) Data Management. See http://ags.org.uk/group/datamanagement/ (accessed 15/06/2017).

Bartel S and Janssen G (2016) Underground spatial planning perspectives and current research in Germany. Tunnelling and Underground Space Technology 55: 112-117.

Bell FG (2003) Geology and construction. In UNESCO Encyclopedia of Life Support Systems (EOLSS). EoLSS Publishers Co., Ltd, Paris, France. BGS (2017a) Legal Framework. National Geological Records Centre (NGRC). See http://www.bgs.ac.uk/services/ngdc/records/policy.html (accessed 15/06/2017).

BGS (British Geological Survey) (2017b) National workshop for LDP policy teams - increasing evidence base to LDP policy. BGS - Improvement Service Workshop, Scotland, 3 May 2017. Workshop flyer.

Bland J, Walthall S and Toll D (2014) The development and governance of the AGS format for geotechnical data. In Information Technology in Geo-Engineering: Proceedings of the 2nd International Conference (ICITG), vol. 3, pp. 67-74. IOS Press, Durham, UK.

Bobylev N (2009) Mainstreaming sustainable development into a city's master plan: a case of urban underground space use. Land Use Policy 26(4): 1128-1137.

Bonsor H (2017) NERC Briefing Note - Integrating NERC(BGS) Subsurface Environmental Research and Data to City Development Processes and Policy: Key Learning Outcomes. BGS, Nottingham, UK, OR/17/005.

Bonsor HC, Entwisle DC, Watson S et al. (2013) Maximising past investment in subsurface data in urban areas for sustainable resource management: a pilot in Glasgow, UK. Technical note. Ground Engineering 46(2): 25-28.

BRO (Basisregistratie Ondergrond) (2017a) Basisregistratie Ondergrond (BRO). See https://bro.pleio.nl/ (accessed 30/05/2017) (in Dutch).

BRO (2017b) Gegevens in de BRO. See https://bro.pleio.nl/ gegevensindebro (accessed 26/06/2017) (in Dutch).

BSI (2014) PAS 128:2014 Specification for underground utility detection, verification and location. BSI, London, UK.

BSI (2017) PAS 256:2017 Buried assets. Capturing, recording, maintaining and sharing of location information and data. Code of practice. BSI, London, UK.

Campbell SDG, Merritt JE, Dochartaigh BÉÓ et al. (2010) 3D geological models and their hydrogeological applications: supporting urban development - a case study in Glasgow-Clyde, UK. Zeitschrift der Deutschen Gesellschaft für Geowissenschaften 161(2): 251-262.

Channel Tunnel Act 1987 (1987) Elizabeth II. Chapter 53. Her Majesty's Stationery Office, London, UK

City of London (2013) Local Plan. December 2013. Department of the Built Environment, City of London Corporation, London, UK.

Cost (European Cooperation in Science and Technology) (2017) SubUrban. See http://sub-urban.squarespace.com/ (accessed 21/12/2017).

Costello SB, Chapman DN, Rogers CDF and Metje N (2007) Underground asset location and condition assessment technologies. Tunnelling and Underground Space Technology 22(5): 524-542.

Crossrail Act 2008 (2008) Elizabeth II. Chapter 18. The Stationery Office, London, UK.

Curiel-Esparza J, Canto-Perello J and Calvo MA (2004) Establishing sustainable strategies in urban underground engineering. Science and Engineering Ethics 10(3): 523-530

Darroch N, Beecroft M and Nelson JD (2016) A conceptual framework for land use and metro infrastructure. Infrastructure Asset Management 3: 122-131.
DCLG (Department for Communities and Local Government) (2016) Planning Practice Guidance. See https://www.gov.uk/government/ collections/planning-practice-guidance (accessed 20/06/2017).

Deelstra T and Girardet H (2000) Urban agriculture and sustainable cities. In Growing Cities Growing Food: Urban Agriculture on the Policy Agenda (Bakker N, Dubbeling M, Gündel S, Sabel-Koshella U and de Zeeuw H (eds)). ZEL, Feldafing, Germany, pp. 43-66.

Defra (Department for Environment, Food and Rural Affairs) (2014) Groundwater (Water Framework Directive) (England) Direction 2014. Policy paper. Defra, London, UK.

DfT (Department for Transport) (2015) Ecorys Streetworks Lane Rental Evaluation. Independent report. DfT, London, UK.

Dick G (2017) Adventures in geoplanning. Presented at Cost Sub-Urban Conference, Bucharest, Hungary.

Doyle MR (2016) From hydro/geology to the streetscape: Evaluating urban underground resource potential. Tunnelling and Underground Space Technology 55: 83-95.

EC (European Community) (1991) Council Directive 91/271/EEC of 21 May 1991 concerning urban waste water treatment. Official Journal of the European Communities L135: 40-52.

EC (1998) Commission Directive 98/15/EC of 27 February 1998 amending Council Directive 91/271/EEC with respect to certain requirements established in Annex I thereof. Official Journal of the European Communities L67: 29-30.

EC (2000) Directive 2000/60/EC of the European Parliament and of the Council of 23 October 2000 establishing a framework for Community action in the field of water policy. Official Journal of the European Communities L327: 1-73.

EC (2001) Directive 2001/42/EC of the European Parliament and of the Council of 27 June 2001 on the assessment of the effects of certain plans and programmes on the environment. Official Journal of the European Communities L197: 30-37.

EC (2006a) Directive 2006/21/EC of the European Parliament and of the Council of 15 March 2006 on the management of waste from extractive industries and amending Directive 2004/35/EC. Official Journal of the European Communities L102: 15-34.

EC (2006b) Directive 2006/118/EC of the European Parliament and of the Council of 12 December 2006 on the protection of groundwater against pollution and deterioration. Official Journal of the European Communities L372: 19-31.

EC (2007a) Directive 2007/2/EC of the European Parliament and of the Council of 14 March 2007 establishing an Infrastructure for Spatial Information in the European Community (Inspire). Official Journal of the European Communities L108: 1-14.

EC (2007b) Directive 2007/60/EC of the European Parliament and of the Council of 23 October 2007 on the assessment and management of flood risks. Official Journal of the European Communities L288: 27-34.

EC (2008) Directive 2008/98/EC of the European Parliament and of the Council of 19 November 2008 on waste and repealing certain Directives. Official Journal of the European Communities L312: 3-30.

EC (2009) Directive 2009/28/EC of the European Parliament and of the Council of 23 April 2009 on the promotion of the use of energy from renewable sources and amending and subsequently repealing directives 2001/77/EC and 2003/30/EC. Official Journal of the European Communities L140: 16-62.

EC (2011) Directive 2011/92/EU of the European Parliament and of the Council of 13 December 2011 on the assessment of the effects of certain public and private projects on the environment. Official Journal of the European Communities L26: 1-21.

EC (2014) Directive 2014/52/EU of the European Parliament and of the Council of 16 April 2014 amending Directive 2011/92/EU on the assessment of the effects of certain public and private projects on the environment. Official Journal of the European Communities L124: 1-18. 
Civil Engineering

Volume 171 Issue CE6
The hidden role of the subsurface for cities

von der Tann, Metje, Admiraal and Collins
European Commission (2011) Cities of Tomorrow - Challenges, Visions, Ways Forward. Directorate-General for Regional and Urban Policy, European Commission, Brussels, Belgium.

European Commission (2017) Urban Development. See http://ec.europa. eu/regional_policy/en/policy/themes/urban-development/ (accessed 25/05/2017)

European Commission (n.d.) About Inspire. See http://inspire.ec.europa. eu/about-inspire/563 (accessed 26/06/2017).

Foster S and Hirata R (2011) Groundwater use for urban development: enhancing benefits and reducing risks. SIWI Water Front 2011: 21-29.

GCC (Glasgow City Council) (2017a) City Development Plan Supplementary Guidance, SG5: Resource Management, 29 March 2017. Glasgow City Council, Glasgow, UK.

GCC (2017b) City Development Plan, February 2017. Glasgow City Council, Glasgow, UK.

Goodwin P (2005) Utilities' Street Works and the Cost of Traffic Congestion. University of West England, Bristol, UK.

HM Land Registry (2015) HM Land Registry Plans: Boundaries (Practice Guide 40, Supplement 3). See https://www.gov.uk/government/ publications/land-registry-plans-boundaries/land-registry-plansboundaries-practice-guide-40-supplement-3 (accessed 19/09/2017).

HMG (Her Majesty's Government) (1994) Water, England and Wales. The Urban Waste Water Treatment Regulations 1994. The Stationery Office, London, UK, Statutory Instrument 1994 No. 2841.

HMG (2003) Water, England and Wales. The Urban Waste Water Treatment (England and Wales) (Amendment) Regulations 2003. The Stationery Office, London, UK, Statutory Instrument 2003 No. 1788.

HMG (2004) Environmental Protection. The Environmental Assessment of Plans and Programmes Regulations 2004. The Stationery Office, London, UK, Statutory Instrument 2004 No. 1633.

HMG (2009a) Environmental Protection, England and Wales. The Groundwater (England and Wales) Regulations 2009. The Stationery Office, London, UK, Statutory Instrument 2009 No. 2902

HMG (2009b) Environmental Protection. Public Sector Information. The Inspire Regulations 2009. The Stationery Office, London, UK, Statutory Instrument 2009 No. 3157

HMG (2009c) Environmental Pretection. The Flood Risk Regulations 2009. The Stationery Office, London, UK, Statutory Instrument 2009 No. 3042.

HMG (2010) Environmental Protection England and Wales. The Environmental Permitting (England and Wales) Regulations 2010. The Stationery Office, London, UK, Statutory Instrument 2010 No. 675

HMG (2011) Environmental Protection, England and Wales. The Waste (England and Wales) Regulations 2011. The Stationery Office, London, UK, Statutory Instrument 2011 No. 988

HMG (2012) Environmental Protection. Public Sector Information. The Inspire (Amendment) Regulations 2012. The Stationery Office, London, UK, Statutory Instrument 2012 No. 1672

HMG (2015) Electricity, England and Wales. The Renewables Obligation Order 2015. The Stationery Office, London, UK, Statutory Instrument 2015 No. 1947.

HMG (2017a) Water Resources, England and Wales. The Water Environment (Water Framework Directive) Regulations 2017. The Stationery Office, London, UK, Statutory Instrument 2017 No. 407

HMG (2017b) Town and Country Planning. The Town and Country Planning (Environmental Impact Assessment) Regulations 2017. The Stationery Office, London, UK, Statutory Instrument 2017 No. 571

HMG (2017c) Infrastructure Planning. The Infrastructure Planning (Environmental Impact Assessment) Regulations 2017. The Stationery Office, London, UK, Statutory Instrument 2017 No. 572.

House of Commons (2016) Comparison of the Planning Systems in the Four UK Countries. House of Commons Commons Library Briefing Paper 07459. House of Commons, London, UK

Hunt DVL, Nash D and Rogers CDF (2014) Sustainable utility placement via multiutility tunnels. Tunnelling and Underground Space Technology 39: 15-26.
London Assembly (2016) MD2009 London Infrastructure Mapping Application - Phase 2 Development. See https://www.london.gov.uk/ decisions/md2009-london-infrastructure-mapping-application-phase2-development (accessed 20/06/2017)

Meuser H (2010) Contaminated Urban Soils, Environmental Pollution 18. Springer Science \& Business Media BV, Dordrecht, the Netherlands.

MtU (Mapping the Underworld) (2012) Project Summary. See www.mappingtheunderworld.ac.uk (accessed 25/05/2017)

National Grid (2017) Supporting Future Energy Use in London. See www.Iondonpowertunnels.co.uk (accessed 21/12/2017).

Nelson PP (2016) A framework for the future of urban underground engineering. Tunnelling and Underground Space Technology 55: 32-39.

Phull R (2017) PAS 256 is Here! Increasing the Quality, Accuracy and Reliability of Data for Buried Infrastructure. See https://www.ice.org uk/news-and-insight/the-civil-engineer/april-2017/pas-256-is-hereincreasing-the-quality (accessed 12/06/17)

Planning Act 2008 (2008) Elizabeth II. Chapter 29. The Stationery Office, London, UK.

Price SJ, Ford JR, Cooper AH and Neal C (2011) Humans as major geological and geomorphological agents in the Anthropocene: the significance of artificial ground in Great Britain. Philosophical Transactions of the Royal Society of London A: Mathematical, Physical and Engineering Sciences 369(1938):1056-1084.

Rawlins BG, Harris J, Price S and Bartlett M (2015) A review of climate change impacts on urban soil functions with examples and policy insights from England, UK. Soil Use and Management 31(S1): 46-61.

Reynolds E and Reynolds P (2015) Planning for underground spaces "NYLon underground". In Think Deep: Planning, Development and Use of Underground Space in Cities. (Admiraal H and Narang Suri S (eds)). International Society of City and Regional Planners (ISOCARP), The Hague, the Netherlands

RPG (Raumplanungsgesetz) (2015) Bundesgesetz ueber die Raumplanung, Entwurf, 05.12.2014. See https://www.are.admin.ch/are/de/home/ raumentwicklung-und-raumplanung/raumplanungsrecht/revision-desraumplanungsgesetzes--rpg-/revision-des-raumplanungsgesetzes--rpg---2--etappe.html (accessed 10/06/2017) (in German).

Scalenghe R and Marsan FA (2009) The anthropogenic sealing of soils in urban areas. Landscape and Urban Planning 90(1): 1-10.

Sterling R, Admiraal H, Bobylev N, et al. (2012) Sustainability issues for underground space in urban areas. Proceedings of the Institution of Civil Engineers - Urban Design and Planning 165(4): 241-254

Tegtmeier W, Zlatanova S, Van Oosterom PJM and Hack HRGK (2014) 3D-GEM: geo-technical extension towards an integrated 3D information model for infrastructural development. Computers \& Geosciences 64: 126-135.

Thomas AM, Rogers CDF, Chapman DN, Metje N and Castle J (2009). Stakeholder needs for ground penetrating radar utility location. Journal of Applied Geophysics 67(4): 345-351.

UN (United Nations) (2001) Atlas of Urban Geology, Vol. 12 Integrating Geology in Urban Planning. ESCAP, Bangkok, Thailand.

UN (2003) Atlas of Urban Geology, Vol. 14. The Ground Beneath Our Feet: A Factor in Urban Planning. ESCAP, Bangkok, Thailand.

UN (2017) Sustainable Development Goals, United Nations Development Program. See http://www.undp.org/content/undp/en/ home/sustainable-development-goals.html (accessed 27/06/2017).

UN Habitat III (n.d.) The New Urban Agenda, Issue Papers. See http:// habitat3.org/the-new-urban-agenda/documents/issue-papers/ (accessed 27/06/2017).

Watson C, Jenson NP, Ryżyński G, Majer K and Hansen M (2017) Data Acquisition \& Management. TU1206 Cost Sub-Urban WG2 Report. See www.sub-urban.eu (accessed 30/05/2017).

Whitbread K, Dick G and Campbell D (2016) Glasgow. TU1206 Cost Sub-Urban WG1 Report. See http://www.sub-urban.eu (accessed 31/01/2017). 